水文・水資源学 会 誌 J. Japan Soc. Hydrol \& Water Resour. Vol. 15, No. 6 (2002) pp. 569-583

\title{
季節性を持つ水文時系列に基づくPDS法とAMS法の比較
}

\section{A Comparison between PDS Method and AMS Method Based on the Generation of Hydrological Time Series with Seasonality}

\author{
西岡昌秋*（侏建設技術研究所大阪支社） \\ Masaaki NISHIOKA Osaka Branch Office, CTI Engineering Co., Ltd \\ 宝 馨** (京都大学防災研究所水災害研究部門) \\ Kaoru TAKARA Disaster Prevention Research Institute, Kyoto University
}

This paper compares AMS (Annual Maximum Series) method with PDS (Partial Duration Series) method in hydrologic frequency analysis through a Monte Carlo experiment. The numerical experiment takes into account the seasonality inherent in hydrologic processes. Based on 174 two-day areal rainfall series in 43 years and 117 flood peak discharge series in 47 years, statistical analysis has revealed the difference between the actual occurrence process and the Poisson process that holds for rare events.

For two series of two-day rainfalls and peak discharges, the Monte Carlo experiment deals with distribution of occurrence interval and distribution of extreme rainfalls and discharges. The exponential distribution for inter event time is used for the Poisson process, while the empirical distributions obtained by the statistical analysis are used for seasonal rainfall and discharge series.

The experiment has revealed the importance of the effect of seasonality. When applying the GEV (Generalized Extreme Value) distribution to AMS, one would overestimate 100-year quantile because of ignoring the seasonality. However, if the quantile estimate obtained by the GP (Generalized Pareto) distribution for PDS is almost the same as the one by GEV-AMS approach, the use of GEV can be justified. It was also concluded that the average number of PDS elements in a year should be four or more to avoid the overestimation by the GEV-AMS approach.

Key words : Partial duration series, Annual maximum series, Monte Carlo simulation, Inter event time, Seasonality

本研究は, 43年間174個の流域平均 2 日雨量と47年間117個の洪水ピーク流量を用いて, 水文頻度解析における毎年最大値系列 (AMS)を使う方法と闒值超過系列(PDS)を使う方法の比較を行ったものである．豪雨や洪水を対象に統計解析を行い，これらの 事象の発生を取り披う場合に，その生起時間間隔の季節性を考慮することが重要であることを示した. これらの事象の発生過程は， 統計的時系列解析でしばしば仮定されるポアソン過程とは実際には異なることに留意しなければならない。

次に，閥値を超過する水文事象の生起時間間隔の確率分布とその水文量の確率分布とを考慮したモンテカルロシミュレーション による数值実験を行った，生起時間間隔の分布としては，季節性のないポアソン過程にもとづく指数分布を用いる場合と，豪雨や

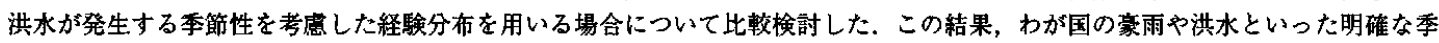
節性をもつ水文事象に対して, 単純にAMSを抽出し, 一般化極値 (GEV)分布をあてはめて確率水文量を推定する場合，遇大な確 率水文量が求められる可能性が高いことを示している。ただし，PDSとしての水文事象の一年間の平均生起個数が 4 個程度以上で あるか,もしくはAMS解析とPDS解析による確率水文量の結果が一致する場合には，AMSに適用した一般化極値(GEV)分布は精 度の良い確率水文量を与える。

キーワード: 閥値超過系列, 毎年最大值系列, モンテカルロシミュレーション, 生起時間間隔, 季節性

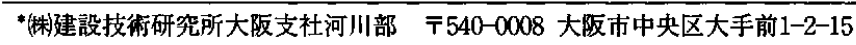

Osaka Branch Office, CTI Engineering Co., Ltd., 1-2-15, Otemae, Chuo-Ku, Osaka, 540-0008, Japan

**京都大学防災研究所水災害研究部門洪水災害分野 $\overline{\mathbf{\tau}} 611-0011$ 京都府宇治市五ヶ生

Disaster Prevention Research Institute, Kyoto University, Uji, Kyoto, 611-0011, Japan 


\section{I . はじめに}

水文統計解析において扱う標本の考え方は大きく 分けて，極値系列 (extreme value series) と闒值超過 系列(partial duration series. PDSまたはpeaks-overthreshold，POT)とに分類される．わが国の治水計画 でよく用いられてきたのは，極值系列のうちの毎年 最大值系列 (annual maximum series, AMS)である.

閥值超過系列(PDS)を対象とした水文統計解析に 関して，海外に拉いて比較的多くの研究事例がある (例えば, Cunnane, 1973, 1979；Rosbjerg, 1985; Rasmussen, 2001). わが国においても，近年では，毎年 最大值系列(AMS)に加え，閾値超過系列(PDS)を对 象とした水文統計解析がおこなわれるようになって いる(星，1998；田中・宝，2001).PDSによる水文統 計解析を行う場合, 閾値の設定方法が問題となる.

これについては， 1 年間の事象の平均生起数が1.65 以上あれば，指数分布によるPDS解析がGumbel分 布によるAMS解析よりも精度が高いとされている (Cunnane, 1973, 1989).これは, 事象の発生過程と して定常ポアソン過程を仮定し，PDSの事象の大き さが指数分布にしたがう場合, AMSがGumbel分布 にしたがうという理論にもとづいている.

本論文では,

(1)これまでのように，AMSを水文統計解析に用い

られることが妥当かどうか

(2)AMSの代わりにPDSを用いた方が良いとしても， そのときのAMSとPDSのPoisson過程に基づく理 論的関係をそのまま用いてよいのかどうか という点について，数値実験により明らかにするこ とを目的としている.

ここでは，わが国の洪水や豪雨のような水文事象 の発生過程は, 季節性を持ち, 上記のポアソン過程 とは異なることを示し，このような事象に对する PDS法とAMS法との比較検討を行った.

この結果, わが国の豪雨や洪水といった明確な季 節性をもつ水文事象に対して, 単純にAMSを抽出 し，一般化極値 (GEV) 分布をあてはめて確率水文量 を推定する場合，過大な確率水文量が求められる可 能性が高いことを示した.

まず, 洪水ピークと豪雨の生起時間間隔を統計解 析した。これらの発生過程は，季節性を持ち， GEV分布導出で仮定されるポアソン過程とは異な ることを示す.

さらに，実測の生起時間間隔と水文量のそれぞれ

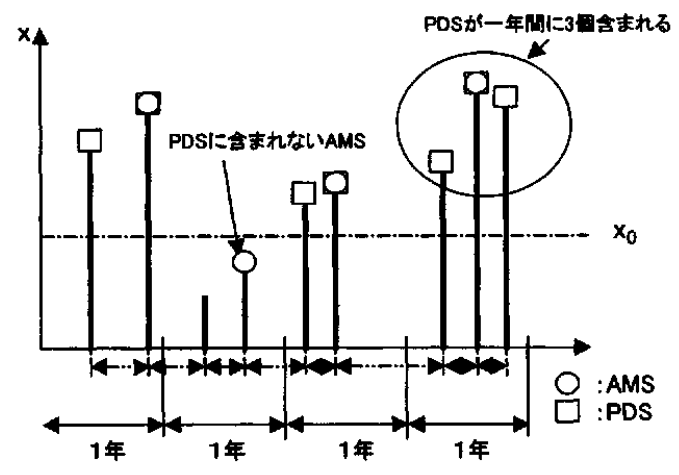

図-1 PDSとAMSとの関係

Fig. 1 Illustration of PDS and AMS

にあてはめた確率分布にもとづくモンテカルロシ ミュレーションによる数值実験を行った。この実験 では, 発生させたPDSからAMSを抽出し, PDSと AMSに関する統計解析を行い, 確率水文量や確率 分布の母数の比較を行った.このとき, 生起時間間 隔の分布として，季節性がないポアソン過程にした がう指数分布と，季節性を考慮した経験分布を考え ることとした.

以下本論文において示されるように，わが国の豪 雨や洪水といった明確な季節性をもつ水文事象に对 して, 単純にAMSを抽出し, 一般化極値 (GEV) 分 布をあてはめて確率水文量を推定する場合, 過大な 確率水文量が求められる可能性が高い.ただし, 閾 值を超過する事象の一年間の平均生起個数が 4 個程 度以上であるか，もしくはAMS法とPDS法による 確率水文量の結果が一致する場合には，AMSに一 般化極值 $(\mathrm{GEV})$ 分布を適用して精度の良い確率水文 量が得られる可能性が高い.

\section{II．閶值超過系列に関する統計理論}

\section{1. 生起時間間隔}

閥值超過系列の発生に対しては，その事象が生起 する間隔を再現する必要がある，この生起間隔が期 間 $t$ を超えない確率を $P\{r<t\}=F(t)$ とする．希な 事象の生起間隔と生起個数については，ポアソン過 程が成立するといわれている．単位時間内における 事象の発生率を入としたとき，ある期間 $t$ における 事象の生起個数 $N$ は, 平均值を $\lambda t$ とするポアソン分 布

$$
P\{N=n\}=\frac{(\lambda t)^{n} e^{-\lambda t}}{n !}
$$


にしたがい, 事象の生起間隔は，平均値を $1 / \lambda$ と する指数分布

$$
F(t)=1-e^{-\lambda t}
$$

にしたがうというものである(伊藤・亀田，1977）.

\section{2. 壹象の大きさの確率分布}

1) PDSとAMSとの関係

ポアソン過程にしたがう事象において発生率を入 とすると, 期間 $t$ に生起する事象の生起個数の期待 值は $\lambda t$ となる。これを水文事象にあてはめて考え る.期間として一年をとると，一年間の事象の生起 数の期待値は $\lambda$ となり，一年間に生起する水文事象 の生起個数の分布は, (1)式において $t=1$ としたポ アソン分布にしたがう。 また，閾值 $x_{0}$ を超え， $X \leq x$ となる事象の確率を $\left.G(x)=P|X \leq x| x \geq x_{0}\right\}$ とする と, この事象の発生率 $\lambda *$ は,

$$
\lambda_{*}=\lambda\{1-G(x)\}
$$

となり, 生起個数 $N^{\prime}$ の確率分布も発生率 $\lambda_{*}$ のポア ソン分布にしたがい,

$$
P\left\{N^{\prime}=n\right\}=\frac{\lambda_{*}^{n} e^{-\lambda_{*}}}{n !}
$$

となる.

次に, この事象に対応する每年最大值の確率分布 (cdf) $F_{a}(x)=P\{X \leq x\}$ とする. $F_{a}(x)$ は一年間を通 じて $x$ 超えない確率を表す。したがって，(4)式に おいて $n=0$ とおけば，(3)式を考虑して

$$
F_{a}(x)=\exp \{-\lambda(1-G(x))\}
$$

が得られる(Stedinger, et al., 1993; 星，1998)。

$\mathrm{AMS} の$ 再現期間を $T_{a}, \mathrm{PDS}$ り得られる再現期 間を $T_{p}$ とすると, $T_{a}$ と $T_{p}$ との関係は,

$$
\frac{1}{T_{a}}=1-\exp [-\lambda|1-G(x)|]=1-\exp \left(-\frac{1}{T_{p}}\right)
$$

で表される。

\section{2）事象の大きさの確率分布}

PDSの水文量には一般化パレート(GP)分布, AMSの水文量には一般化極值 (GEV) 分布が適合す ると言われている.ある闘値を超過する事象の水文 量に対してGP分布を仮定し，その発生過程がポア ソン過程にしたがう場合, その系列から得られる AMSはGEV分布にしたがうことが理論的に2. 1)の 関係から求められる(Stedinger, et al., 1993)。すなわ ち，一般化パレート分布

$$
G(x)=1-\left[1-\frac{\kappa}{a}\left(x-x_{0}\right)\right]^{\frac{1}{k}}
$$

ただし，

$$
\kappa<0, x_{0} \leq x<\infty
$$

$\kappa>0, x_{0} \leq x \leq x_{0}+a / \kappa$

$\kappa$ : 形状母数, $a$ : 尺度母数, $x_{0}$ : 位置母数 を(5)式に代入すると，GEV分布が求められる。

$$
\begin{aligned}
F_{a}(x) & =\exp \left[-\lambda\left\{1-\frac{\kappa}{a}\left(x-x_{0}\right)\right\}^{\frac{1}{\alpha}}\right] \\
& =\exp \left[-\left\{1-\frac{\kappa}{a_{a}}(x-c)\right\}^{\frac{1}{x}}\right]
\end{aligned}
$$

ただし，

$$
\kappa<0, c+a_{a} / \kappa<x
$$$$
\kappa>0, x<c+a_{a} / \kappa
$$

$\kappa$ : 形状母数, $a_{a}$ : 尺度母数, $c$ : 位置母数

GP分布とGEV分布の母数の関係は，

$$
\left.\begin{array}{l}
a_{a}=a \lambda^{-x} \\
c=x_{0}+\frac{a}{\kappa}\left(1-\lambda^{-\kappa}\right)
\end{array}\right\}
$$

(7)式および(8)式において， $\kappa=0$ の場合は，(7)式 のGP分布が指数分布

$$
G(x)=1-\exp \left\{-\frac{1}{a}\left(x-x_{0}\right)\right\}
$$

となり，(8)式のGEV分布がGumbel分布

$$
F_{a}(x)=\exp \left\{-\exp \left(-\frac{x-c}{a}\right)\right\}
$$

となる、母数の関係は，

$$
c=x_{0}+a \ln (\lambda)
$$

\section{III. 凟料の概要と統計解析}

\section{1 . 使用する水文量}

本研究では，治水計画に扔ける水文統計解析を想 定し, 河川流域における流域平均 2 日雨量と洪水 ピーク流量を用いる。

\section{1）流域平均 2 日雨量}

わが国のある河川の基準地点上流域の43年間にわ たる流域平均 2 日雨量(日単位雨量を用いてティーセ ン法により算定)を用いた。

流域内の代表的な 3 つの観測所を選定し，日雨量 が100m超える降雨事象もしくは時間雨量が $30 \mathrm{~mm}$ を超える一連の降雨事象を収集した. PDS解析を行 うため，年間第 2 位以下の降雨が含まれるように， 1 年間に少なくとも 5 つの事象を収集することによ り合計485事象を収集した，その際，降雨が 3 日以 上連続する事象の場合，その中で最大の 2 日雨量を 採用した.すなわち， $\Delta d \geqq 1.0$ となるようにした。 これらの雨量資料は, ある観測所における時間単 
位の雨量が大きいものの, 観測所地点の総雨量や流 域平均単位での総雨量でみた場合には，非常に小さ い降雨となる場合がある。このため,これらの雨量 資料から, ある閥值以上の降雨資料を抽出した. 闘 值は, PDS法とAMS法との比較検討を実施する観 点から, 流域平均 2 日雨量の毎年最大值資料の最小 値とした。このようにすると，PDSに含まれない AMSがないこととなる。この結果, 合計174個の降 雨資料を得た。

\section{2) ピーク流旦}

ピーク流量は, 湿潤温帯地域のある河川流域にお ける雨量データを用いて, 流出モデルにより変換し た流量模擬系列から求めた。

雨量データは以下のようにして収集した。流域内 の降雨分布を代表すると考えられる雨量観測所を選 定しこれらの観測所における年間第 3 位までの雨 量資料を46年間収集した. さらに，水系内の基準地 点における流量観測資料や水位資料を参考に，年間 第 3 位程度までの流量を生起させる降雨事象を包含 しているかチェックした．年間第 3 位程度までを選 定するのは, PDS解析を行うため, 年間第 2 位以下 の洪水も含まれるようにするためめであ.

流出モデルは貯留関数法を使用した. 水系内基準 地点において選定した複数の洪水を対象に, 基準地 点の観測流量と計算流量とを比較し，モデル定数の 妥当性を検証した。このモデル定数は全ての事象に 対して一定值を与えた. 流出解析から得られる流量 時系列の最大値をピーク流量として抽出した.

\section{2. 統計的特性}

流域平均 2 日雨量およびピーク流量の資料に関す る統計的特性をそれぞれ衰一 1 ，表一 2 ，および表 一3，表一 4 に示す.

ある事象 $i$ の生起日を $d i$, その次の事象 $i+1$ の生 起日を $d_{i+1}$ とした場合, 時間間隔 $\Delta d_{i}=d_{i+1}-d_{i}$ を “生 起時間間晍”と呼ぶ.ここで用いた流域平均 2 日雨 量の場合は，降雨の始まりと終わりの時刻が分かっ ているので，その中央時刻を到とした．図一2は生 起時間間隔を月別に集計し，その平均値，最大値お よび最小值を示している，11月の最小値は120日， 最大值は260日であることから，11月に生起した豪 雨の次の豪雨は，その年の 12 月および翌年の 1 月に は生起しない。

図一3はピーク流量の生起時間間隔を月別に集計 し, その平均值, 最大值および最小值を示している.
10月の最大值は260日，最小值は110日であり，10月 に生起した洪水の次の洪水は，その年の11月，12月 には生起しない.

\section{3. 生起時間間隔の確率分布}

流域平均 2 日雨量とピーク流量の生起時間間隔 $\Delta d$ の頻度分布に指数分布をあてはめた結果を図一 4 お よび図ー 5 に示す，次の水文事象までの生起時間間 隔であることから，ここに図示する事象の数は, (もとの事象数一1)個となる. 流域平均 2 日雨量, ピーク流量ともに，300日付近で極大値をもつよう な分布形となっており，単調減少の指数分布とはな

表-1 流域平均 2 日雨量資料の統計的特性

Table 1 Characteristics of 2-day areal rainfall

\begin{tabular}{c|ccc}
\hline & 平均 & 標準偏差 & $\begin{array}{c}\text { ひずみ } \\
\text { 係数 }\end{array}$ \\
\hline 雨量(PDS) & $177.8 \mathrm{~mm}$ & $79.9 \mathrm{~mm}$ & 1.689 \\
雨量(AMS) & $259.7 \mathrm{~mm}$ & $99.6 \mathrm{~mm}$ & 0.811 \\
生起間隔 & 89 日 & 104 日 & 1.328 \\
年間生起数 & 4.05 個 & - & - \\
\hline
\end{tabular}

表-2 月別の生起個数 (流域平均 2 日雨量) Table 2 Number of events (2-day areal rainfall)

\begin{tabular}{c|cccccc}
\hline 月 & 1 月 & 2 月 & 3月 & 4 月 & 5 月 & 6 月 \\
個数 & 0 & 1 & 2 & 14 & 7 & 27 \\
\hline 月 & 7 月 & 8 月 & 9 月 & 10 月 & 11 月 & 12 月 \\
個数 & 24 & 45 & 39 & 10 & 5 & 0 \\
\hline
\end{tabular}

表-3 ピーク流年資料の統計的特性

Table 3 Characteristics of peak discharge

\begin{tabular}{c|ccc}
\hline & 平均 & 樏準偏差 & $\begin{array}{c}\text { ひずみ } \\
\text { 係数 }\end{array}$ \\
\hline ピーク流量 & 1655 & 1077 & 0.987 \\
(PDS) & $\mathrm{m}^{3} / \mathrm{s}$ & $\mathrm{m}^{3} / \mathrm{s}$ & 0.987 \\
ピーク流量 & 2385 & 1127 & 0.433 \\
(AMS) & $\mathrm{m}^{3} / \mathrm{s}$ & $\mathrm{m}^{3} / \mathrm{s}$ & 0.634 \\
生起間隔 & 141 日 & 134 日 & 0.63 \\
年間生起数 & 2.54 個 & - & - \\
\hline
\end{tabular}

表-4 月別の生起個数 (ピーク流量)

Table 4 Number of events (Peak discharge)

\begin{tabular}{c|cccccc}
\hline 月 & 1月 & 2月 & 3月 & 4月 & 5月 & 6 月 \\
個数 & 0 & 1 & 2 & 8 & 4 & 27 \\
\hline 月 & 7 月 & 8 月 & 9 月 & 10 月 & 11 月 & 12 月 \\
個数 & 24 & 20 & 23 & 7 & 0 & 1 \\
\hline
\end{tabular}




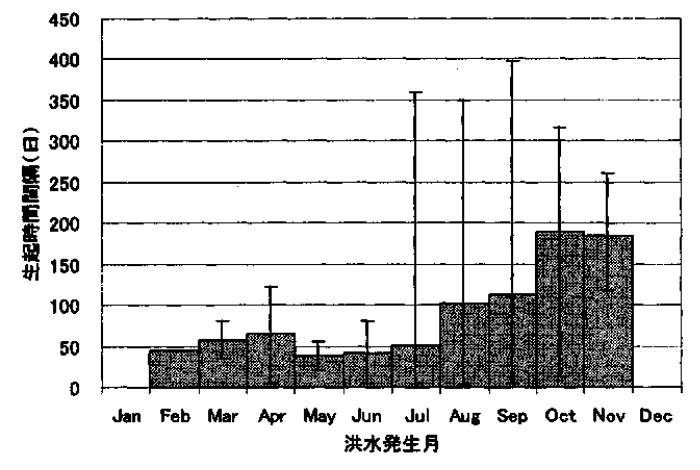

図-2 2 日雨量に関する生起時間間隔の統計旦 (最大値および最小值の範囲を併記)

Fig. 2 Average and range of inter event time (2-day areal rainfall)

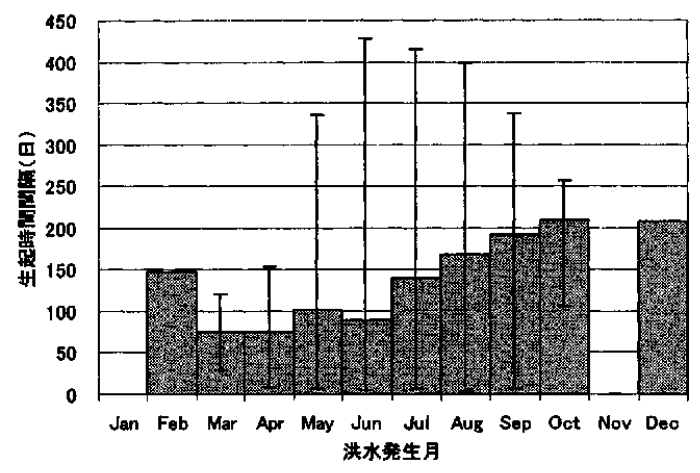

図-3ピーク流量に関する生起時間間隔の統計量 (最大值扔よび最小值の範囲を表示)

Fig. 3 Average and range of inter event time (Peak discharge)

らないことがわかる.なお，而１で述べたように $\Delta d \geqq 1.0$ であるが, ここでは $\Delta d \geqq 0$ としている. $0 \leqq \Delta d \leqq 1$ となるのは, 流域平均 2 日雨量で約 $1 \%$, ピーク流量で約 $0.6 \%$ である.

\section{4. 生起時間間隔と水文量の大きさの相関関係 1）流域平均 2 日雨量}

生起時間間隔と流域平均 2 日雨量との相関係数を 図一6に示す. 図中の棒グラフは相関係数(值は左 側の縦軸で表示)を, けのプロットはデータの個数 (値は右側の維軸で表示)を示す．横軸は事象の発生 した月を表す。ただし, 最も左側に示す值は 173 個 全てのデー夕に関する結果を示す.173個全体での 相関係数はー0.005であり, 流域平均 2 日雨量の大 きさと生起時間間隔との間に相関はないと言える。

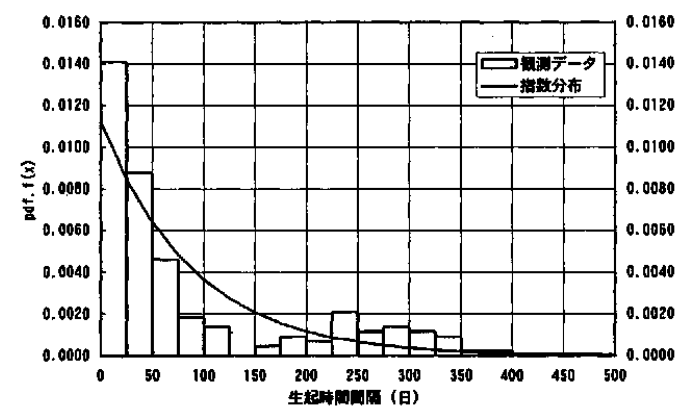

图-42 日雨量に関する生起時問間隔の頻度分布

Fig. 4 Frequency of inter event time on 2-day areal rainfall (Empirical and exponential distributions)

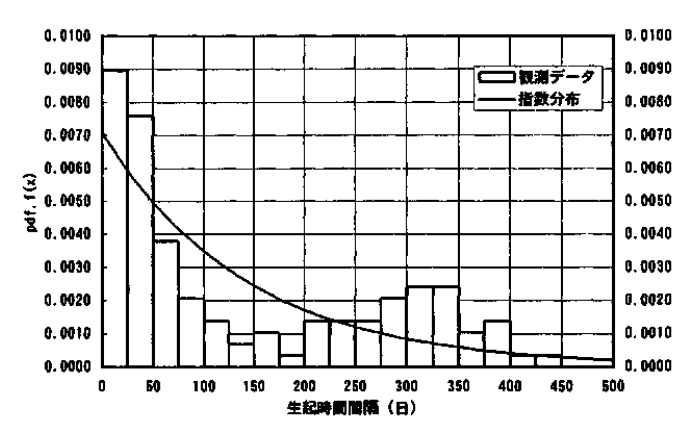

図-5 ピーク流量に関する生起時問間隔の頻度分布

Fig. 5 Frequency of inter event time on peak discharge (Empirical and exponential distributions)

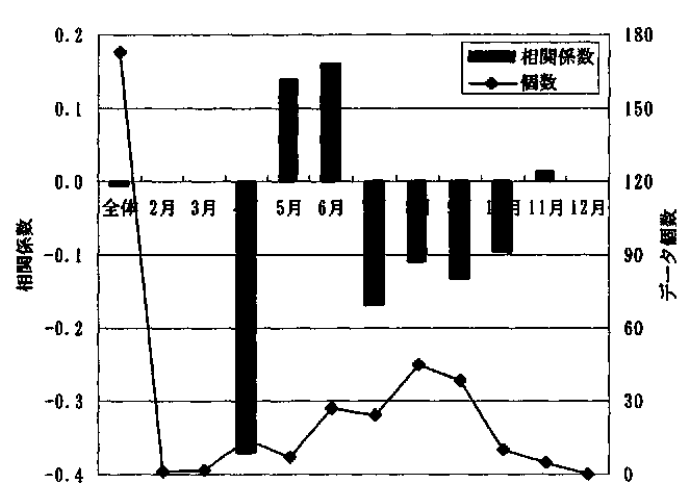

図-6 生起時間間隔と流域平均 2 日雨量の相関保数 (৬: 相関係数を算定したデー夕個数)

Fig. 6 Correlation coefficient between inter event time and 2-day areal rainfall ( $\bullet$ : Number of data calculated correlation coeffcient) 


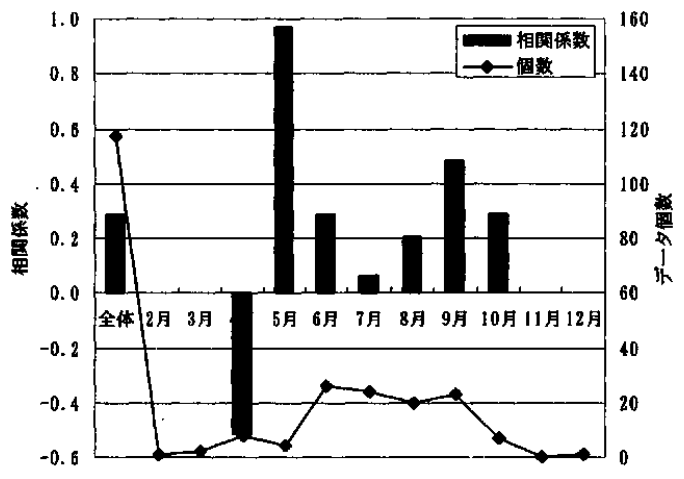

図-7 生起時問間隔とピーク流量の相関係数 (け：相関係数を算定したデータ個数）

Fig. 7 Correlation coefficient between inter event time and peak discharge (Number of data calculated correlation coeffcient)

\section{2) ピーク流量}

ピーク流量について同様に整理した結果を図一7 に示す. 全洪水(116個)の相関係数は0.291であり， 流域平均 2 日雨量よりもわずかに相関係数は大きい が，生起時間間隔とピーク流量との相関関係は無い と言える。月別にみた場合には，5月に発生した洪 水の生起時間間隔とピーク流量との相関係数が 0.967 とみかけ上高い值を示すが，このときのデー 夕個数は 4 個である.

\section{5. 水文量の確率分布}

\section{1) PDS解析}

収集した174個の流域平均 2 日雨量を標本として 3 母数の一般化パレート分布 (GP分布)を，L積率法 によりあてはめた，適合度の指標であるSLSC (standard least-squares criterion)は，0.03以下の場合，標 本と理論値との適合度が良いことが知られている (宝，1998)。表一5に示すように，GP分布はSLSC が0.018であることから，標本との適合度が高いこ とが分かる.

ピーク流量についてもGP分布のSLSCは0.017で あり適合度が高い(表一 6 参照)。

\section{2) AMS解析}

流域平均 2 日雨量のPDSからAMS(43個)を抽出 し，水文統計解析を行った(表一7)，GEV(一般化䓧 値) 分布 ( L 積率法)の適合度SLSCは0.028であり，標 本との適合度が良好であることを示している.

ピーク流量についても同様にGEV分布のSLSCは
表一 5 PDSの統計解析結果 (流域平均 2 日雨量)

Table 5 Goodness of fit (SLSC) and 100-year quantile estimated for several distributions: PDS (2-day areal rainfall)

\begin{tabular}{|c|c|c|c|}
\hline 分布形 & 央数推定法 & SLSC & $\begin{array}{c}\text { 磼率水文量 } \\
(T=100 \text { 年) }\end{array}$ \\
\hline $\mathrm{GP}$ & L㘔率法 & 0.018 & $560.2 \mathrm{~mm}$ \\
\hline $\begin{array}{l}\text { 対数ピア } \\
\text { ソンIII型 }\end{array}$ & 対数標本の積率法 & 0.031 & $665.7 \mathrm{~mm}$ \\
\hline 対数正規 & 石原 · 高瀬法 & 0.045 & $585.4 \mathrm{~mm}$ \\
\hline 対数正規 & 岩井法 & 0.039 & $611.7 \mathrm{~mm}$ \\
\hline
\end{tabular}

\section{表-6 PDSの統計解析結果 (ピーク流量)}

Table 6 Goodness of fit (SLSC) and 100-year quantile estimated for several distributions: PDS (Peak discharge)

\begin{tabular}{|c|c|c|c|}
\hline 分布形 & 母数推定法 & SLSC & 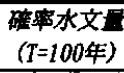 \\
\hline $\mathrm{GP}$ & L程率法 & 0.017 & $5120 \mathrm{~m}^{3} / \mathrm{s}$ \\
\hline $\begin{array}{l}\text { 対数ピア } \\
\text { ソンIII型 }\end{array}$ & 対数標本の糟率法 & 0.016 & $6182 \mathrm{~m}^{3} / \mathrm{s}$ \\
\hline $\begin{array}{l}\text { 対数正規 } \\
\text { 対数正規 }\end{array}$ & $\begin{array}{c}\text { 石原 - 高瀬法 } \\
\text { 岩井法 }\end{array}$ & $\begin{array}{l}0.028 \\
0.020\end{array}$ & $\begin{array}{l}5775 \mathrm{~m}^{3} / \mathrm{s} \\
7416 \mathrm{~m}^{3} / \mathrm{s}\end{array}$ \\
\hline
\end{tabular}

\section{表-7AMSの統言十解析結果 (流域平均 2 日雨量)}

Table 7 Goodness of fit (SLSC) and 100-year quantile estimated for several distributions: AMS (2-day areal rainfall)

\begin{tabular}{|c|c|c|c|}
\hline 分布形 & 母数推定法 & SLSC & $\begin{array}{c}\text { 確率水文吾 } \\
(T=100 \text { 年) }\end{array}$ \\
\hline GEV & L積率 & 0.028 & $549.3 \mathrm{~mm}$ \\
\hline Gumbel & L榡率 & 0.023 & $580.5 \mathrm{~mm}$ \\
\hline $\begin{array}{l}\text { 対数ビア } \\
\text { ソンIII型 }\end{array}$ & 対数橒本の皘率法 & 0.023 & $551.2 \mathrm{~mm}$ \\
\hline 対数正規 & 石原・高澒法 & 0.025 & $563.2 \mathrm{~mm}$ \\
\hline 対数正規 & 岩井法 & 0.022 & $543.8 \mathrm{~mm}$ \\
\hline
\end{tabular}

\section{衰-8 AMSの統計解析結果(ピーク流量)}

Table 8 Goodness of fit (SLSC) and 100-year quantile estimated for several distributions: AMS (Peak discharge)

\begin{tabular}{|c|c|c|c|}
\hline 分布形 & 母数推定法 & SLSC & $\begin{array}{c}\text { 磪率水文 } \\
(T=100 \text { 年 })\end{array}$ \\
\hline GEV & L㯖率 & 0.024 & $5645 \mathrm{~m}^{3} / \mathrm{s}$ \\
\hline Gumbel & L䄼率 & 0.032 & $6141 \mathrm{~m}^{3} / \mathrm{s}$ \\
\hline $\begin{array}{l}\text { 対数ピア } \\
\text { ソンIII型 }\end{array}$ & 対数樽本の積率法 & 0.024 & $5763 \mathrm{~m}^{3} / \mathrm{s}$ \\
\hline 対数正規 & 石原 - 高瀬法 & 0.027 & $5438 \mathrm{~m}^{3} / \mathrm{s}$ \\
\hline 対数正規 & 岩井法 & 0.027 & $6201 \mathrm{~m}^{3} / \mathrm{s}$ \\
\hline
\end{tabular}


0.024であり，標本との適合度が良好である(表一 $8)$.

N. モンテカルロシミュレーションによるPDS 法とAMS法の比較

\section{1．生起時間間隔の分布モデル}

ポアソン過程にしたがって発生する事象の生起時 間間隔は，指数分布にしたがうことが知られている. しかし，ここで用いた豪雨や洪水の事象の生起時間 間隔は，30日以下と 300 日付近で極大值をもち，単 調減少の指数分布とはならない，さらに，豪雨では 12月から 3 月に, 洪水では11月から 3 月に，それぞ れの事象の生起数が, 他の月と比較して少ないとい う季節性が見られる. 本研究では, 生起時間間隔の 季節性に着目し, 以下の 3 つの生起時間間隔の分布 を考え比較する.

(1)指数分布にしたがうと考える(季節性がない)

(2)季節性を配慮した経験分布にしたがうと考える

(3)経験分布にしたがうと考えるが季節性を考えない

\section{2. 水文量の大きさの確率分布モデル}

水文量の大きさの確率分布は, PDSに対しては GP分布で良好に表されることがわかった.このこ とから，水文量の大きさは，それぞれの資料から推 定される母数をもつGP分布にしたがって発生させ る.また, 生起時間間隔と事象の大きさとの間には 相関関係がみられないことから独立であると仮定し， それぞれの分布にしたがうように独立に発生させる。

3. シミュレーションの方法

シミュレーションは以下のように行った.

1 ) 生起時間間隔が指数分布にしたがう場合

\section{手順 1)}

生起時間間煽の分布 $\left(F_{t}(t)\right.$ と表す $)$, すなわち指数 分布にしたがう乱数を $(n-1)$ 個発生させ, 生起時 間間隔 $t$ 算定する.

手順 2)

事象の大きさの分布 $\left(F_{p}\left(x_{p}\right)\right.$ と表す), すなわち $\mathrm{GP}$ 分布にしたがう乱数を $n$ 個発生させる.

手順 3 )

手順 1) から手順 2)の手順を $m$ 回繰り返して行う.

2）季節性を配虚した生起時間間隔の経験分布に したがう場合

生起時間間隔が季節性をもつと考える場合には， 月別に生起時間間隔の分布が異なる。このため, 初
期值，すなわち 1 個目の事象の生起日により，それ 以降の事象の生起日が異なる. したがって, 初期値 を月別の発生個数の経験分布にしたがって発生させ る必要がある、シミュレーションの手順は以下のと おりである。

\section{手順 1)}

一様乱数を 1 個発生させ, 豪雨の場合は表一 2 に, 洪水の場合は表一 4 に示した月別の事象の生起個数 の累積分布に応じた日数 $\left(\iota_{0}\right.$ 日)を求める. 計算開始 日から数えて $t_{0}$ 日後を 1 個目の事象の生起日とする.

\section{手順 2)}

生起時間間隔の月別の経験分布にしたがうよう に，2個目以降の事象を発生させる。ただし，事象 の生起日が標本の経験分布では発生していない月 (例えば流域平均 2 日雨量では 1 月と12月)になる場合, その乱数は用いないこととした。これは，事象の発 生しない月に生起する場合, その次の事象を発生さ せることができないためである.

\section{手順 3 )}

事象の大きさの発生方法は 1 )の手順 2 ) と同様で ある.

\section{手順 4)}

手順 1)から手順 3）を $m$ 回繰り返す.

3）生起時間間隔が季節性を考慮しない経験分布 にしたがう場合

上記の 1 ) 手順 1 )における指数分布のかわりに生 起時間間隔の経験分布を採用し，これにしたがうよ うな乱数を発生させる.あとの手順は，1)と同様 である.

乱数の発生組数は $m=100$ とし, 乱数の発生個数 は $n=10000$ とした。

ただし，1）と 2)については，流域平均 2 日雨量 に対しては $n=400$, ピーク流量に対しては $n=200$ のケースを追加した． 1 年間に生起する事象の平均 は, 流域平均 2 日雨量の場合 4.05 個, ピーク流量の 場合2.54個である。したがって, 発生させた 10000 個のデータから抽出した毎年最大値系列の大きさが, 流域平均 2 日雨量の場合は 100 個程度, ピーク流量 の場合は80個程度得られる。これらのケースは, 毎 年最大值系列を用いた水文統計解析を行う場合，今 日我々が得ることのできる標本の大きさを想定した ものである.

ある分布にしたがう乱数を発生させる場合，一様 乱数を発生させて得られた 0 から 1 までの乱数系列 から, 所定の確率分布の逆関数を用いて変換する. 


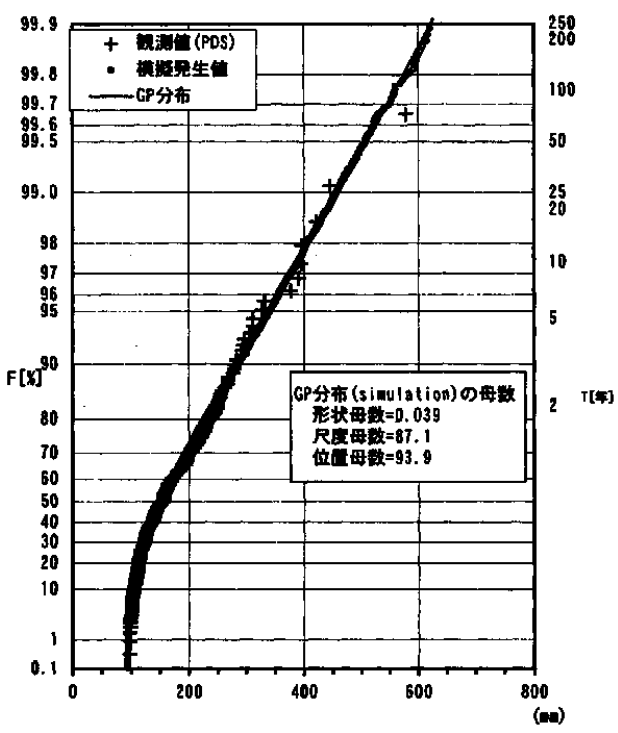

図-8 PDSの観測值にあてはめたGP分布と発生し た系列

Fig. 8 Observed PDS and GP distribution applied to it (1000 PDS generated by the distribution are also shown)

本研究では, 一様乱数の発生は, 富士通科学用サブ ルーチンライブラリSSL【の，Lehmerによる合同 法による手法を採用したサブルーチン「RANU2」 を用いた。

\section{V. 統計解析の結果}

\section{1. 記号の説明}

本章では，水文量等の記号を以下のように記述す る.

$$
\begin{aligned}
& x_{o, p d s} \text { : 収集したPDSの観測データ系列 } \\
& x_{0, \text { ans }}: x_{0, \text { dds }} \text { から抽出したAMS } \\
& x_{r, \text { ds }} \text { : GP分布にしたがう乱数を発生させて得 } \\
& \text { られたPDS } \\
& x_{r, \text { ans }}: x_{r, \text { des }} \text { から抽出したAMS } \\
& G P_{o, p d s} ： x_{o, \text { pds }} \text { にあてはめたGP分布 } \\
& G P_{r, p d s} ： x_{r, p d s} \text { にあてはめたGP分布 } \\
& G E V_{o, a n n}: x_{0, a n s} に \text { あてはめたGEV分布 } \\
& G E V_{r, \text { ans }}: x_{r, \text { ans }} \text { にあてはめたGEV分布 } \\
& \hat{x}_{r, 100}: x_{r, \text { ans }} \text { のプロッティングポジションから内 } \\
& \text { 挿により推定した } 100 \text { 年確率水文量 } \\
& \hat{x}_{8,100}: x_{r, a n s} \text { にあてはめたGEV分布より推定さ } \\
& \text { れる100年確率水文量 }
\end{aligned}
$$

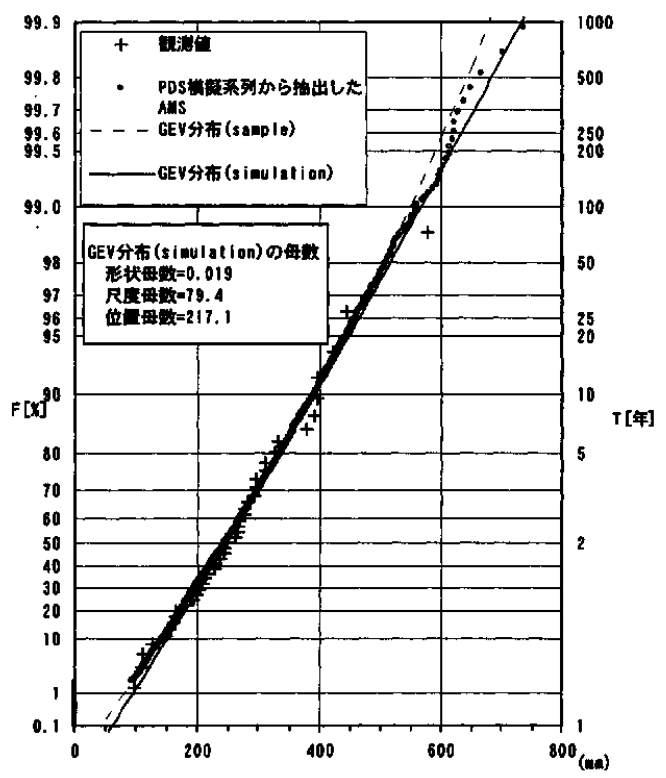

図-9 AMSの観測值にあてはめたGEV分布とPDS (模擬系列) から抽出したAMSにあてはめた GEV分布の例(生起時間間隔が指数分布にした がう場合）

Fig. 9 An example of GEV distributions applied to observed AMS and extracted AMS from generated PDS (Inter event time: exponential distribution)

\section{2. 流域平均 2 日雨量}

1) 確率紙での比較

a）生起時間間谝が指数分布にしたがう場合

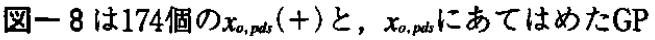
分布 $G P_{o, p d s}$ (実線)㧍よび10000個の乱数を発生させて 得られた $x_{r, \text { ds }}(O)$ とをGumbel確率紙にプロットした 結果である. プロッティングポジションはCunnane 公式

$$
F_{i}=\frac{i-\alpha}{n+1-\alpha}
$$

ただし，

$$
\begin{aligned}
& n: \text { デー夕数 } \\
& i: \text { 資料を小さい方から並べたときの順位 } \\
& \alpha=0.4
\end{aligned}
$$

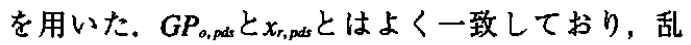
数発生の精度が高いことを示している。

発生させた 10000 個の $x_{r, p d s}$ から抽出したAMS $x_{r, \text { ans }}$ にGEV分布を適合させた. $m=1$ の結果をGumbel 確率紙にプロットした(图ー9参照)，10000個のPDS に対して, 乱数の発生組によりAMSの個数は異な 


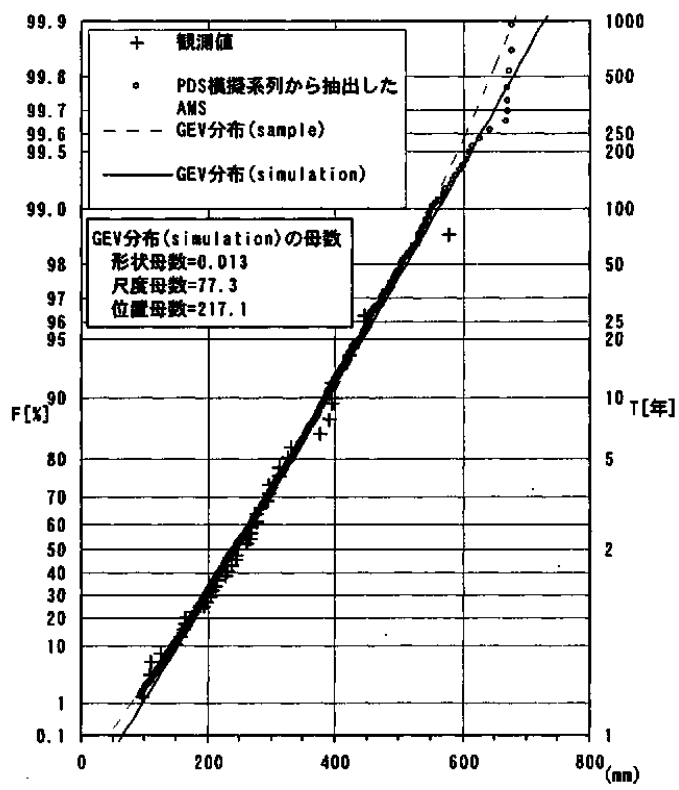

図-10 AMSの観測値にあてはめたGEV分布とPDS (模擬系列)から抽出したAMSにあてはめた GEV分布の例(季節性を考虑した経験分布に生 起時間間隔がしたがう場合)

Fig. 10 An example of GEV distributions applied to observed AMS and extracted AMS from generated PDS (Inter event time: empirical distribution considering seasonality)

る.100組のPDSに対してAMSは平均的には2439個 得られた。図ー9に示した $m=1$ の場合は2429個で ある. $x_{0, \text { ans }}(+), x_{\text {r,ans }}(O), G E V_{o, a m s}$ (破 線)，GEV r,ams (実線)の 4 つの分布は全般的に一致している.

图一4に示したように，生起時間間隔を指数分布 にしたがい発生させた場合，次の豪雨までの時間間 隔が 1 年以上となる場合が約 $2 \%$ ある，生起時間間 隔が 1 年以上となる場合に, 豪雨が生起しない年が 発生する.この豪雨の発生していない年の毎年最大 值を $0 \mathrm{~mm}$ とした. 生起時間間隔が 1 年以上となり豪 雨が発生しない年は, 100回のシミュレーションで 2400 年程度のうち平均的に 40 年存在した. $x_{r, a m s}$ が 0 $\mathrm{mm}$ となるところでの $x_{0, a n n}$ との一致度は低い.

b）生起時間間隔が季節性を考慮した経験分布に したがう場合

$x_{r, \text { pats }}$ から抽出したAMS $x_{r, a m s} に G E V$ 分布を適合さ せ， $m=1$ の場合をGumbel確率紙にプロットした 結果を図一10に示す，10000個のPDSに対してAMS は平均的には2463個程度得られた。この方法による

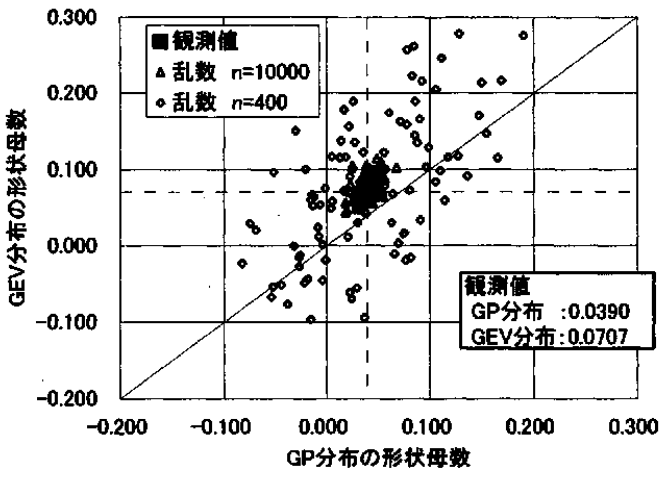

図-11 両分布の形状母数の関係(生起時間間隔が指 数分布にしたがう場合)

Fig. 11 Relationship between shape parameters (Inter event time: exponential distribution)

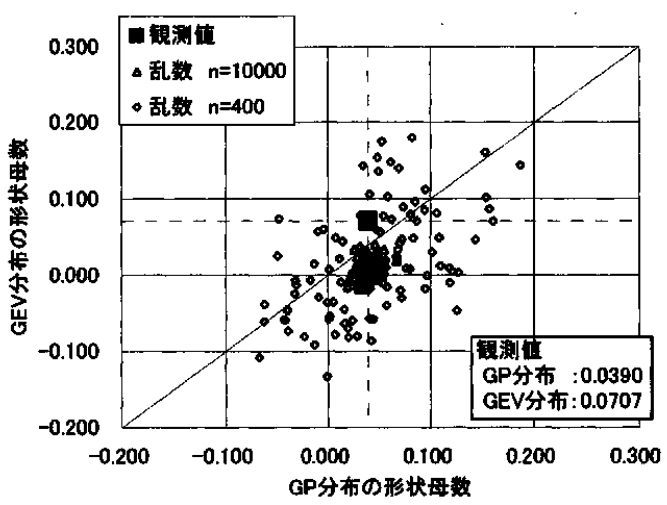

図-12 両分布の形状母数の関係(季節性を考虑した 経験分布に生起時間間隔がしたがう場合)

Fig. 12 Relationship between shape parameters (Inter event time: empirical distribution considering seasonality)

と, a )とは異なり, 生起時間間隔がー年以上にな ることがないため，豪雨は毎年発生する．また， $x_{o, a n s}, x_{r, a n s}, G E V_{o, a n s}, G E V_{r, a n s}$ の 4 つの分布は, $x_{o, a n s}$ の最大値である $578 \mathrm{~mm}$ 以下の範囲でよく一致してい る.

\section{2) 形状母数の比較}

生起時間間隔が指数分布にしたがう場合について， $G P_{r, p d s}$ の形状母数と $G E V_{r, \text { ans }}$ の形状母数の比較を行っ た結果を図一11に示す. $G P_{o, \text { dss }}$ の形状母数 $\kappa=$ $0.0390, G E V_{o, a m s}$ の形状母数 $\kappa=0.0707$ ある. GP 分布およびGEV分布のいずれの形状母数について も，標本での推定值(破線の交点)を中心として，そ の周りに分布している. $n=400 の$ 場合には, $n=$ 


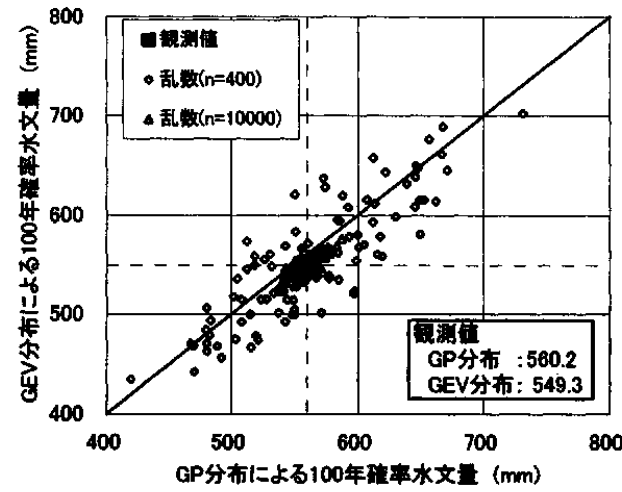

図-13 GP分布とGEV分布から推定した 100 年確率水 文量 (生起時間間隔が指数分布にしたがう場合)

Fig. 13 100-year quantiles estimated by GP and GEV distributions (Inter event time: exponential distribution)

10000の場合と比較してばらつきの度合いが大きい， GEV分布は，形状母数が正のとき上側有界であり， 標本から推定したGEV o.ams のように, Gumbel確率紙 上では下に凸の形状となる. $n=400$ とき， $G E V_{\text {r,ams }}$ の形状母数が負となる場合がある.このこ とは, $G E V_{r, a m s}$ の形状が $G E V_{\text {o,ans }}$ とは異なる場合があ ることを示している.

生起時間間隔が，季節性を考㦄した経験分布にし たがう場合について，同様に比較した結果を図一12 に示す．前述とは異なり，シミュレーションによる 形状母数は標本での推定值を中心としたばらつきを 示さない.これは，ポアソン過程にもとづく理論的 背景を持つGEV分布に対して, シミュレーション では季節性を考虑しているため, ポアソン過程とは 異なる生起時間間隔の発生を行っているためである.

\section{3） 100 年確率水文昷の比較}

生起時間間隔が指数分布にしたがう場合について,

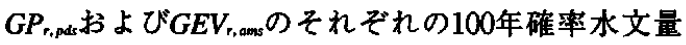
を推定した結果を図一13に示す. 標本加らの推定値

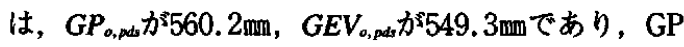
分布の方が大きい值を推定している. $n=10000$ の ときは, 標本からの推定值の周りに分布しており, GP分布の推定値がGEV分布の推定值よりも大きい. $n=400$ のとは，推定値の範囲が大きくなるとと もに, GEV分布の方が大きい推定值となる場合が ある。

生起時間間隔が，季節性を考慮した経験分布にし たがう場合の結果を図ー14に示す. $n=10000$ 場

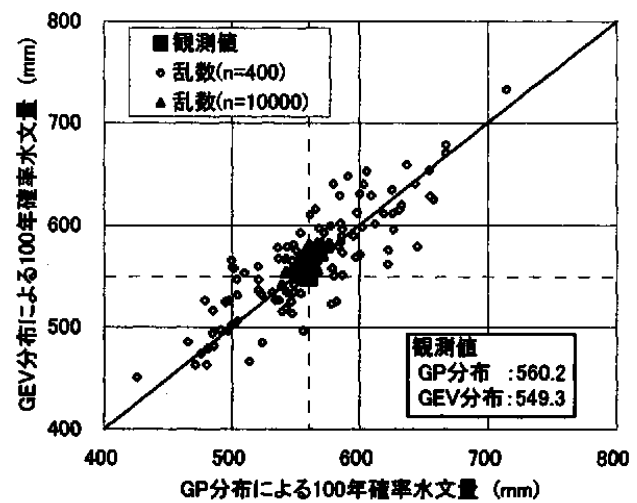

図-14 GP分布とGEV分布から推定した100年確率 水文量(季節性を考虑した経験分布に生起時間 間隔がにしたがう場合)

Fig. 14 100-year quantiles estimated by GP and GEV distributions (Inter event time: empirical distribution considering seasonality)

合，GP分布による確率水文量とGEV分布による確 率水文量はほほ一致している， $n=400$ の場合は, 推定値の変動幅が大きくなり, GEV分布の推定値 がGP分布の推定値よりも大きくなる場合があるの は，前記と同粎である.

\section{3. ピーク流量}

\section{1) 確率秖での比較}

a ）生起時間間隔が指数分布にしたがう場合 流域平均雨量と同粎に, $\boldsymbol{G} P_{o, p d s}$ と模擬発生値 $x_{r, p d s}$ とはよく一致しており，乱数発生の精度が高いこと を示している(图一15参照).

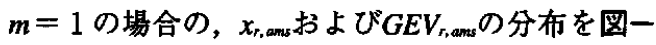
16に示す. 10000個のPDSに対して, AMSは $m=1$ 〜100の平均で3869個得られた。

$x_{r, a n s}$ と $G E V_{r, a n,}$ とは比較的一致している. 流域平均 2 日雨量の場合と同様に, 生起時間間隔を指数分布 にしたがい発生させた場合，次の洪水までの時間間 隔が 1 年以上となる場合が約 $5 \%$ ある. 流域平均 2 日雨量の場合と同様に, 洪水の生起していない年の 毎年最大值は $0 \mathrm{~m}^{3} / \mathrm{s}$ とした。このため $1000 \mathrm{~m}^{3} / \mathrm{s}$ 以

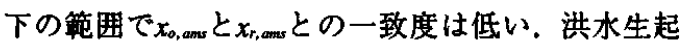
間隔が 1 年以上となり洪水が発生しない年は, 平均 的に3869年間のうち 292 年存在した。

b）生起時間間隔が季節性を考慮した経験分布に したがう場合

$\boldsymbol{x}_{\mathrm{r}, \text { ads }}$ から抽出したAMS $\boldsymbol{x}_{\mathrm{r}, \text { ans }}$ にGEV分布をL積率法 


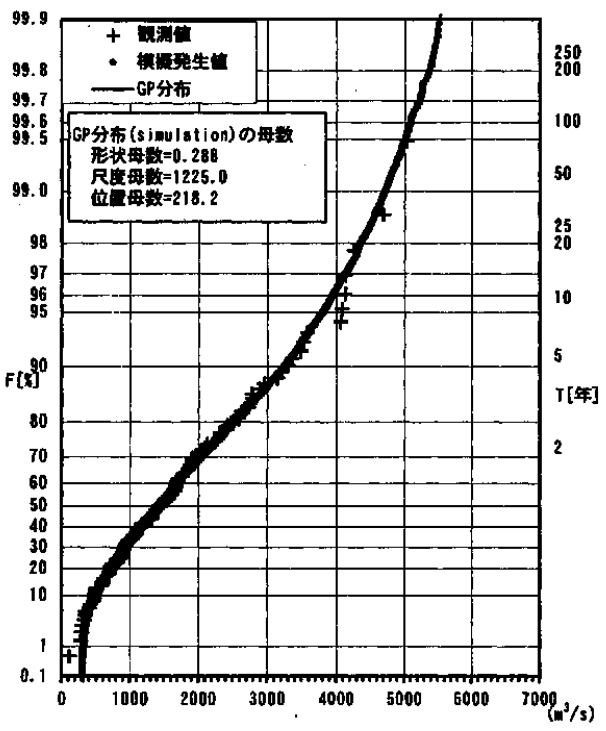

図-15 PDSの観測值にあてはめたGP分布と発生し た系列

Fig. 15 Observed PDS and GP distribution applied to it (10000 PDS generated by the distribution are also shown)

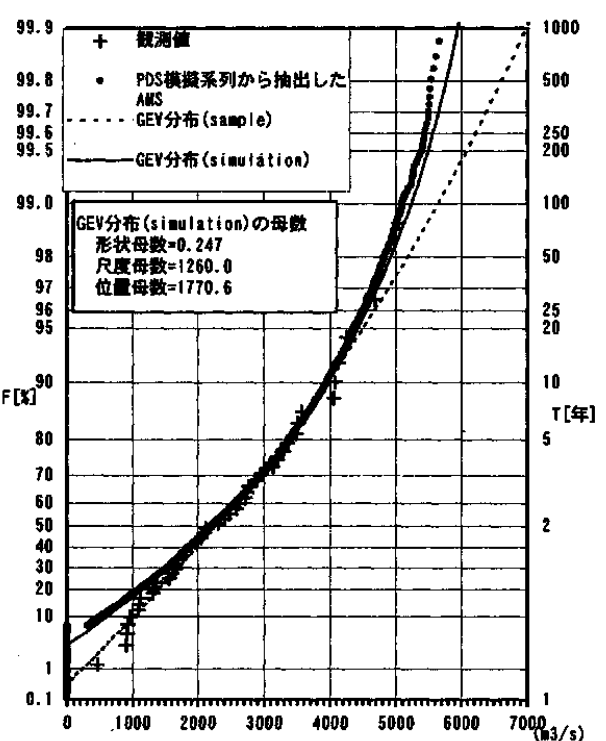

図-16 AMSの観測值にあてはめたGEV分布とPDS から抽出したAMSにあてはめたGEV分布の 例(生起時間間隔が指数分布にしたがう場合)

Fig. 16 An example of GEV distributions applied to observed AMS and extracted AMS from generated PDS (Inter event time: exponential distribution)

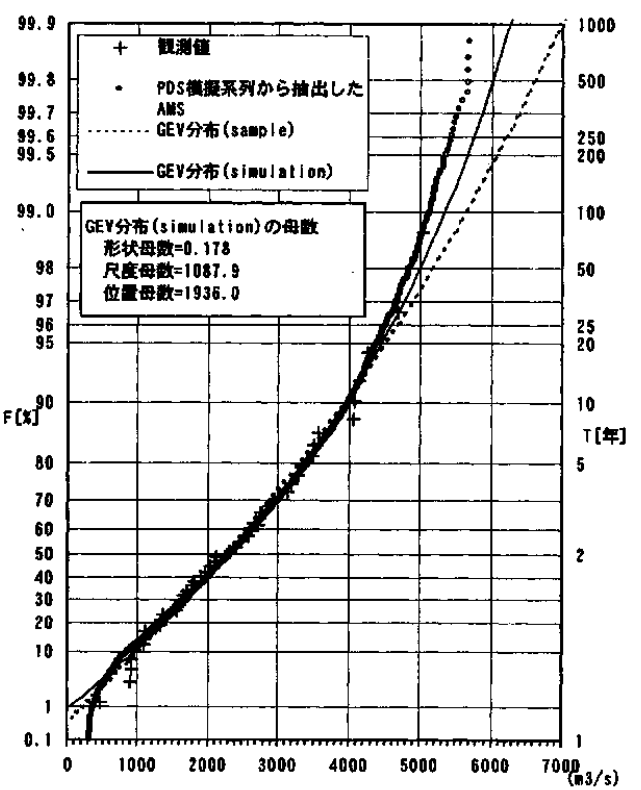

図-17 AMSの観測俌にあてはめたGEV分布とPDS から抽出したAMSにあてはめたGEV分布の 例(季節性を考慮した経験分布に生起時間間隔 がしたがう場合)

Fig. 17 An example of GEV distributions applied to observed AMS and extracted AMS from generated PDS (Inter event time: empirical distribution considering seasonality)

で適合させ， $m=1$ の場合をGumbel確率紙にプ ロットした結果を図一17に示す１0000個のPDSに 对してAMSは平均的には3844個得られた。 この方 法によると，a）とは異なり，洪水は毎年発生する. $x_{r, \text { ans }}$ は全般的に標本 $x_{o, a n s}$ とよく一致している. $\boldsymbol{x}_{r, \text { ans }}$ とあてはめたGEV分布 $G E V_{r, a n s}$ とは, 水文量の 大きい部分での一致度が低い。ここで扱った洪水事 象は，GEV分布の理論的背景であるポアソン過程 とは異なるためである。

c）生起時間間隔が季節性を考虑しない経験分布 にしたがう場合

a) と同様に， $x_{r, p d s}$ から抽出したAMS $x_{r, \text { ans }} に \mathrm{GEV}$ 分布をL積率法で適合させ， $m=1$ の場合をGumbel確率紙にプロットした結果を図一18に示す。 10000個のPDSに対して, AMSは平均的には3839個 得られた. 洪水が発生しない年が平均的に 47 年間存 在するが，a）と比較するとその年数は小さい.

b) と同様に, 水文量の大きい部分に扔いて, $\boldsymbol{x}_{r, \text { ans }}$ とGEV分布との適合度が，a）の場合と比較し 


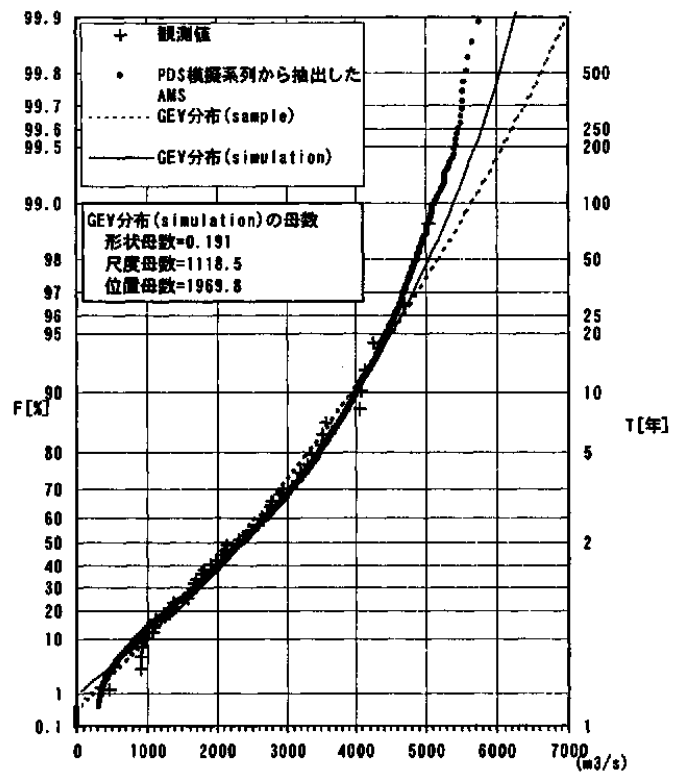

图-18 AMSの觀測值にあてはめたGEV分布とPDS から抽出したAMSにあてはめたGEV分布の 例(季節性を考感しない経験分布に生起時間間 隔がしたがう場合)

Fig. 18 An example of GEV distributions applied to observed AMS and extracted AMS from generated PDS (Inter event time: empirical distribution not considering seasonality)

て悪くなっている。これは, b)の原因と同様と考 えられる，適合度をSLSCで比較すると，図一18の 場合が 0.017 に対して，図一16の場合は0.021である。 ただし，图一16の場合には， $x_{r, a n s}=0 \mathrm{~m}^{3} / \mathrm{s}$ の部分が SLSCを大きくしていると考えられる， $x_{r, a n s}=0 \mathrm{~m}^{3} / \mathrm{s}$ を除いて算出したSLSCは0.007であり，図一18の場 合と比較してSLSCは小さく，適合度は高いと言え る.

\section{2）形状母数の比較}

生起時間間隔が指数分布にしたがう場合について, $G P_{r, \text { pds }}$ の形状母数と $G E V_{r, \text { ans }}$ の形状母数の比較を行っ

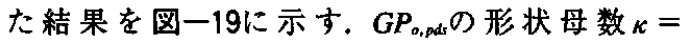
$0.289, G E V_{o, a n s}$ の形状母数 $\kappa=0.098$ である(口のフ ロットで示す)。 GP分布とGEV分布の形状母数は理 論上同一で, 理想的なポアソン過程にしたがうそれ ぞれの分布の形状母数は, 図一19に示すような対角 線上にプロットされる. $n=10000$ の場合をみると， 推定したGP分布とGEV分布の形状母数は，ほほ一 致し対角線付近にプロットされている.

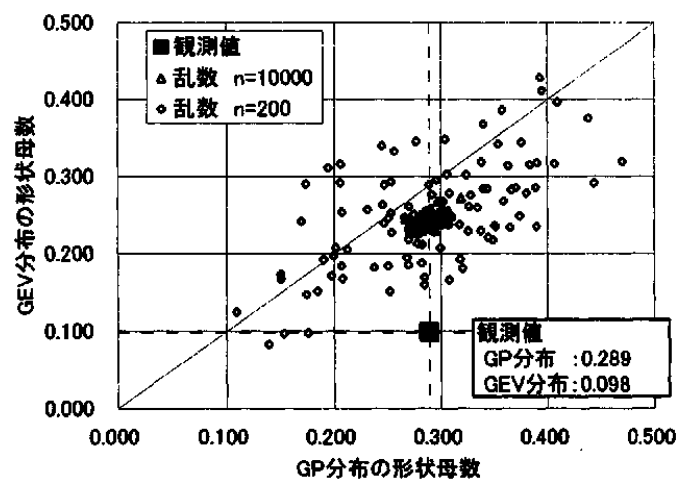

图-19 両分布の形状母数の関係(生起時間間隔が指 数分布にしたがう場合）

Fig. 19 Relationship between shape parameters (Inter event time: exponential distribution)

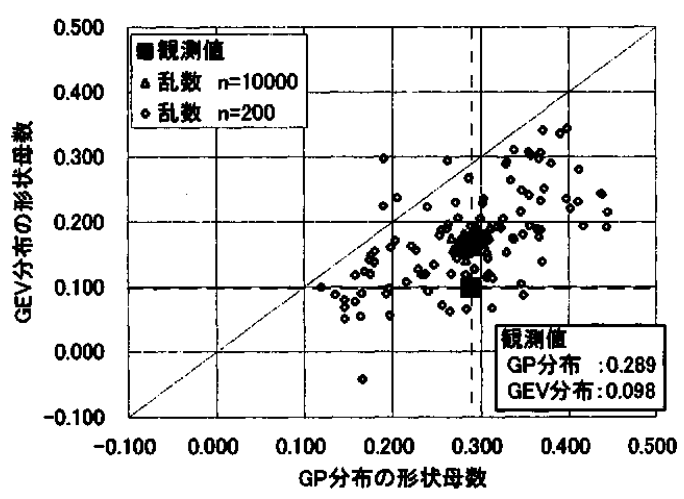

図-20両分布の形状母数の関係(季節性を考虑した 経験分布に生起時間間隔がしたがう場合）

Fig. 20 Relationship between shape parameters (Inter event time: empirical distribution considering seasonality)

次に，生起時間間隔が，季節性を考虑した経験分 布にしたがう場合について，同様に比較した結果を 図一20に示す。このときは，GEV分布の形状母数 がGP分布よりも小さくなり対角線付近から離れる とともに，観測値から推定した形状母数に近づく. このことは, 事象の発生過程がポアソン過程にした がう場合には，再者の形状母数が一致し(対角線に 近づき), ポアソン過程とは異なる季節性を考虑し た場合には, 対角線から離れ, 標本から推定した形 状母数に近づくことを意味している.

3） 100 年確率水文量の比較

生起時間間隔が指数分布にしたがう場合について, $G P_{r, \text { eds }}$ および $G E V_{r, \text { ans }}$ のそれぞれの100年確率水文量 


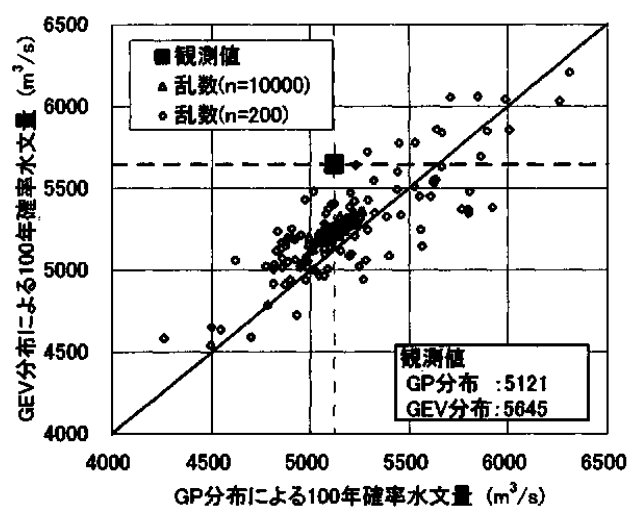

図-21 GP分布とGEV分布から推定した100年確率水 文吾 (生起時間間隔が指数分布にしたがう場合)

Fig. 21 100-year quantiles estimated by GP and GEV distributions (Inter event time: exponential distribution)

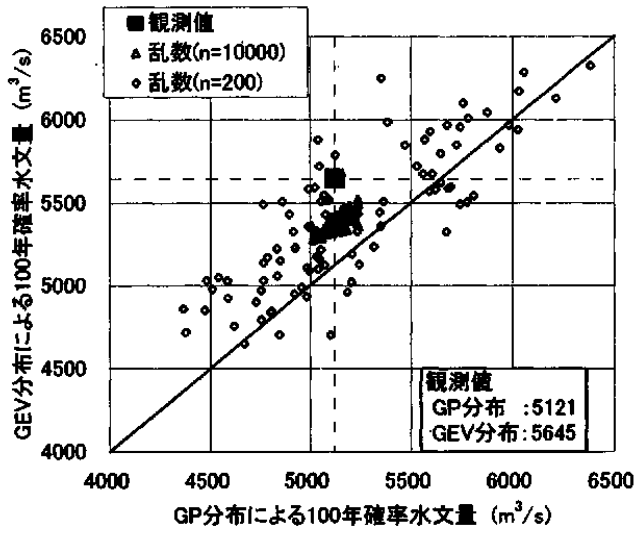

図-22 GP分布とGEV分布から推定した100年確率 水文量(季節性を考慮した経験分布に生起時間 間隔がしたがう場合)

Fig. 22 100-year quantiles estimated by GP and GEV distributions (Inter event time: empirical distribution considering seasonality)

を推定した結果を図一21に示す. 元の標本からの推 定値は, $P G_{o, \text { pds }}$ が $5121 \mathrm{~m}^{3} / \mathrm{s}, G E V_{o, p d s}$ が $5645 \mathrm{~m}^{3} / \mathrm{s}$ であ る. $G E V_{r, a m s}$ の推定值はGP $P_{r, p a s}$ よりも大きい值となる. $n=200$ のときは, $n=10000$ の場合と比較して, ば らつきが大きく, 元の標本からの場合と逆に $G P_{r, \text { d d s }}$ の推定值が大きい場合が100ケースのうち37ケース であった。

生起時間間隔が，季節性を考慮した経験分布にし たがう場合について，同様に比較した結果を図一22

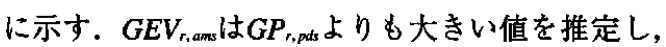

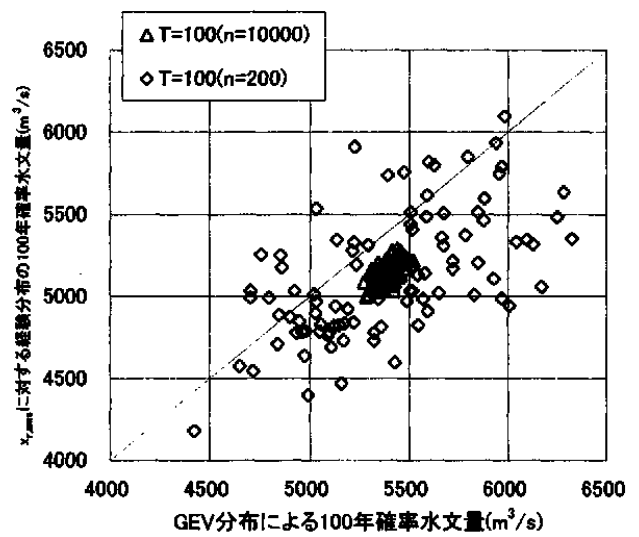

图-23 $\hat{\boldsymbol{x}}_{r, 100} \hat{\boldsymbol{x}}_{8,100}$ の関係(ピーク流量)

Fig. 23 Comparison of $\hat{\boldsymbol{x}}_{r, 100}$ and $\hat{\boldsymbol{x}}_{\mathrm{g}, 100}$ (Peak discharge)

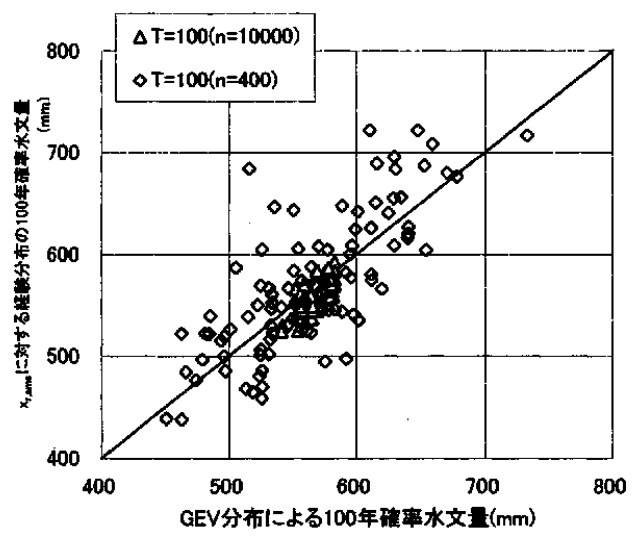

图-24 $\hat{\boldsymbol{x}}_{r, 100}$ と $\hat{\boldsymbol{x}}_{\boldsymbol{8}, 1000}$ の関係 (流域平均 2 日雨量)

Fig. 24 Comparison of $\hat{\boldsymbol{x}}_{r, 100}$ and $\hat{\boldsymbol{x}}_{z, 100}$ (2-day areal rainfall)

図一21の場合よりも対角線から離れる $(n=10000$ の 場合)。これは，図一19扔よび図一20で示した結果 と同様に, 事象の発生過程として, ポアソン過程と 季節性を考慮した発生過程との間の違いを表してい る.

次に, ピーク流量に関して $x_{\text {r,ams }}$ のプロッティング ポジションから内挿により推定した100年確率水文 量 $\hat{x}_{r, 100}$ と， $x_{r, \text { ans }}$ にあてはめたGEV分布より推定し た 100 年確率水文量 $\hat{x}_{8,100}$ とを比較した結果を图一23 に示す. $n=10000$ の場合をみると， $\hat{x}_{8,100 \text { は }} \hat{x}_{r, 100 よ}$ りも大きい値を推定している.10000個のPDSから 抽出した 3800 個程度の標本 $x_{r, \text { anm }}$ よる経験分布が母 分布に限りなく近いと考え，これによる確率水文量 
を真俌とみなすホポアソン過程を仮定できないよう な標本(季節性を考慮しなければならない標本)に対し， GEV分布を適合させて推定される確率水文量は, 母集団に想定される確率水文量(真值)に対して過大 評価をする可能性が高いことを示している．

この結果は, 図一24に示した流域平均 2 日雨量を 標本とした場合と異なる。これについて考えられる 要因は以下の 2 点である.

(1)事象の一年間の平均生起個数

一年間の平均生起個数は, 流域平均 2 日雨量が 4.05個に対し，ピーク流量は2.04個である.PDS の 1 年間に含まれる事象の数が大きいほど, それ より抽出されるAMSが，理想的な毎年最大値の 母集団により近づくためと考えられる.

(2)GP分布により推定した確率水文量とGEV分布に より推定した確率水文量の差異

元のデー夕に対してGP分布から推定した確率 水文量(ここでは100年確率)と GEV分布から推定し た確率水文量とを比較すると, 流域平均 2 日雨量 については，GP分布の推定值が560.2mnに対して GEV分布の推定値が549.3m（誤差=2\%)である. 一方, ピーク流量については, GP分布の推定值が $5120 \mathrm{~m}^{3} / \mathrm{s}$ に対し, GEV分布の推定値は $5645 \mathrm{~m}^{3} / \mathrm{s}$ （誤差=10\%）である.

以上の結果から，GEV分布を用いた確率水文量 の推定を行う場合には, 以下のことを確認する必要 がある。

(1)一年間に閥値を超える事象の平均生起数が 4 個程 度以上ある

(2)GP分布を用いて推定した確率水文量が，GEV分 布を用いて推定した確率水文量と一致する

いずれかの条件が满たされない場合，GEV分布 は母集団の特性を表現しておらず，推定した確率水 文量は過大評価となる可能性が高い.

\section{V. 結 論}

極値水文事象 (流域平均 2 日雨量とピーク流量)の生 起時間間隔に着目し，モンテカルロシミュレーショ ンによる数值実験を通じて, PDS法とAMS法との 関係について調べた，本論文で得られた結果を要約 すると以下のとおりである.

(1)本研究で取り扱った水文量の生起時間間隔は，そ の生起数が冬期には少なく夏期に多いという季節 性を持つことを示した。これは，希な水文事象の 発生過程として一般的に言われるポアソン過程と
は異なるものである。

(2)生起時間間隔の季節性を考慮したモンテカルロ寒 験を行ったところ, 乱数を発生させて得られた PDSから抽出したAMSの経験分布は, 元のデー 夕のAMSとほほ一致する。これは, 本研究で対 象とした水文事象の発生過程が, ポアソン過程と は異なる(季節性をもつ)ことを示している。

(3)乱数を発生させて得られたPDSから抽出した AMSの経験分布による100年確率水文量とその AMSにあてはめたGEV分布による100年確率水文 量とを比較した．ピーク流量を対象とした場合， GEV分布による推定値の方が大きい. 前者の経 験分布による確率水文量の推定值が真值に近いと 考えると, ポアソン過程にもとづくGEV分布に よる確率水文量は, それに比べて過大評価となっ た.このことは, 季節性をもつ水文事象に対して GEV分布をあてはめると, 過大評価となる可能 性が高いことを示している。

(4)流域平均 2 日雨量を対象とした場合には，(3)のよ うな過大評価となる可能性が低い。この理由は， 一年間の水文事象の生起数が平均的に 4 個以上存 在することと, PDS法によるGP分布の確率水文 量と AMS法によるGEV分布の確率水文量とが一 致するためと推察される.

\section{引用文䰚}

伊藤 學・亀田弘行(訳) (1977)：土木建築のための 確率・統計の基碟, p. 120 , 丸善.

星 清 (1998)：洪水ピークの確率評価手法について, 開発土木研究所月報, 539 , pp. 34-47.

宝 整(1998): 水文頻度解析の進歩と将来展望, 水 文・水資源学会誌, 11(7)，pp. 740-756.

田中茂信・宝 整(2001): 洪水頻度解析における AMSとPDSの比較, 水工学論文集, 45, pp. 205210.

Cunnane, C. (1973) : A particular comparison of annual maxima and partial duration series methods of flood frequency prediction, Journal of $\mathrm{Hy}$ drology, 18, pp. 257-271.

Cunnane, C. (1979) : A note on the Poisson assumption in partial duration series models, Water Resources Research, 15(2), pp.489-494.

Cunnane, C. (1989): Statistical distribution for flood frequency analysis, WMO Operational $\mathrm{Hy}-$ drology, Report No.33, WMO-No. 718, Geneva, 
Switzerland.

Stedinger, J R., Vogel, R.M. and Foufoula-Georgiou, E. (1993): Frequency analysis of extreme events, in Handbook of Hydrology, Chap. 18, (ed.) Maidment, D.R., McGraw-Hill, New York.

Rasmussen, P.F. (2001) : Generalized probability weighted moments: Application to the general- ized pareto distribution, Water Resources Research, 37(6), pp. 1745-1751.

Rosbjerg, D. (1985) : Estimation in partial duration series with independent and dependent peak values, Journal of Hydrology, 76, pp. 183-195.

（受付: 2002年 2 月 1 日, 受理：2002年 6 月 7 日） 